\section{Free trade now free?}

Europe's change of heart on agriculture is good for GATT, but US plans on microchips from Japan are not.

THE European Communities (EC) have been thoroughly (and rightly) castigated for causing the breakdown, last December in Brussels, of the negotiations meant to provide for a further bout of trade liberalization in the framework of the General Agreement on Tariffs and Trade (GATT). Can they now expect the indulgence accorded to repentant prodigal sons for having signalled a willingness to be flexible? The sticking-points, last year, were that Europe's offer of a 30 per cent reduction of farm subsidies was calculated with 1986 as the base year (when European subsidies were 10 per cent greater than even now) and that it would not make a separate deal on export subsidies, which are the most direct threat to international trade. Now, the European Commission says that it will, after all, negotiate on the three mechanisms by which it rigs the European market - export subsidies, price supports for farmers and import levies. They are putting out the flags in Geneva, where GATT is based, to signal a resumption of negotiations.

But the cause of trade liberalization, the fastest growing component of the world's economy since the Second World War and the mechanism by which Adam Smith's doctrine that economic wealth rests on the division of labour between efficient producers is literally being made international, is not yet out of the woods. Europe may be willing to negotiate, but may not agree to reduce its protection of agriculture enough to satisfy its chief critics - the United States and the leading agricultural primary producers of the Cairns group (Australia, New Zealand, Argentina and the like).

That is why indulgence will be needed. Europe's critics have consistently failed to appreciate the central role in the Treaty of Rome on which the Economic Communities are founded of the Common Agricultural Policy (CAP), designed to assure 1950s agrarian Europe that farmers would not be impoverished in the intended dash for industrialization. The CAP is now an anachronism and an expensive one, costing Europe perhaps $\$ 100$ million a year (nearly half in direct costs, the rest in the needlessly high cost of food in Europe). It should be abandoned, but Europe's trading partners should be more patient than they seemed to be last year.

There are, in any case, other issues to be settled. The GATT negotiations themselves embed several other time-bombs, the still incomplete agreement on protection for intellectual property among them. But the whole principle of the GATT negotiation is made a monkey of by a development elsewhere - the declared intention of the United States to renew its five-year price-rigging bilateral agreement with Japan on computer memory chips. The original objective, in 1986, was to protect the US chipmaking industry by requiring that Japanese chips should be sold only at inflated prices, and to 'open' the Japanese market to imports from elsewhere.

In the event, the agreement has not functioned as intended. One difficulty is that the government of Japan has been no more able to determine where autonomous manufacturers of computers obtain their components than would have been the government of the United States if the shoe had been on the other foot. The efficient division of labour requires that manufacturers buy their components wherever they can be had most cheaply.

One result is that Japanese chip-makers laugh on the way to their banks. Another is that the cost of memory chips worldwide is greater than it should be. A third is that the pattern of a novel trade is artificially distorted. It is a scandalous agreement, entirely in conflict with the spirit of GATT. On those grounds alone, Japan could (and should) decline to acquiesce, but will probably sign on the dotted line the US Department of Commerce specifies. The question this shabby agreement provokes is whether the United States can be serious about trade liberalization.

\section{Biotechnology of age}

The US administration is seeking a relaxation of regulations - not before time.

BIOTECHNOLOGY has been with us for seventeen years now and, despite scary predictions that genetically engineered organisms would be running rampant across the Earth, there is no record of harm to man or beast. The Bush administration has evidently taken this history of safe research and development into account in formulating its new policy on biotechnology. The report now published (see page 729) from the President's Council on Competitiveness, chaired by Vice-President Dan Quayle, has been prepared by a group whose leader is James B. Wyngaarden, former director of the US National Institutes of Health. It wants to see biotechnology proceed with as little regulation as possible.

The administration's long-awaited policy statement, if implemented, would not only foster biotechnology in the United States, but also have a beneficial effect on collaboration among US scientists and companies and with their colleagues abroad. Meanwhile, the Congress has been given notice that attempts to write new regulations into law will be opposed by the Bush administration.

Scientifically speaking, the new policy is consistent with the recent drift of analyses of risk issues by the National Institutes of Health's Recombinant DNA Advisory Committee (the RAC), which has been pushing for a relaxation of the criteria which determine how many experiments it must oversee. The new policy statement rightly declares that regulators should avoid needless restriction of research and development in this vital technology. Let us hope that people listen.

NATURE · VOL $349 \cdot 28$ FEBRUARY 1991 